\title{
ROMA, RACE AND SOCIALLY ENGAGED TELEVISION ON THE FRINGES OF EUROPE
}

\author{
Martin Yoanis Marinos \\ Penn State University \\ mpm6214@psu.edu
}

\begin{abstract}
This article contributes to the work of scholars of Eastern Europe who insist on the relevance of race and racism to the region. The text analyzes a contemporary Bulgarian documentary TV series, called Nichia Zemia (No Man's Land) and its representation of Roma minorities. The study traces the connections between rising inequalities, poverty, and demographic change that accompany post-socialist neoliberalism and the portrayals of Roma as an external Other, criminals and a demographic threat. The text shows the limits of the concept of ethnicity and highlights the need for a systematic analysis of the role media play in the proliferation of racism in this part of the world.
\end{abstract}

Keywords: Roma, Bulgaria, racism, neoliberalism, post-socialism

\section{Introduction}

An inmate explains that as punishment for a misdeed in prison, the warden of the institution moved him from the "white males" section to the one populated by "tsigani." $\mathrm{A}$ garbage truck blocks a narrow street to the chagrin of a stuck driver who shouts out at the camera that "this would never happen in the white countries." $\mathrm{A}$ popular Roma singer contemplates that if he were a politician the Roma would rather support him than a "white person." 3 These fragments from a Bulgarian documentary TV series called No Man's Land (Nichia Zemia in Bulgarian, NZ from here onwards), which focuses primarily on marginalized individuals hidden from public view and abandoned by the state, hint at a social context permeated by racial anxieties. Yet, in this Balkan country and across Eastern Europe the topic of race and racism rarely enters media and popular discourse. Furthermore, most scholars of the region, both East and West, are also skeptical of the applicability of the concept of race because they view ethnicity as a category more suitable to this part of the world.

Through an analysis which focuses on the representation of the Roma on Bulgarian television, this article seeks to contribute to work that emphasizes the importance of studying race and racism in the post-socialist context. ${ }^{4}$ argue that familiar post-socialist refrains of a 'return to Europe' and 'catching up with the West' reference not just political and economic visions, such as the establishment of electoral democracy and a free market, but new racial arrangements as well. Belonging to the West, sanctified by admission into the European Union, is thus understood, in the formerly socialist states of Eastern Europe, as equivalent to joining 'the white countries,' as the NZ driver above put it. 
However, even as many post-socialist countries have been part of the EU for a while now, a deep divide continues to separate the Western and Eastern parts of the continent. More than three decades after the collapse of socialism the gap between the living standards of Western and Eastern Europe remains very wide, producing a pervasive state of anxiety. The 'backwardness' of East European countries such as Bulgaria is often accounted for by way of alleged cultural differences which mark the Roma as the main impediment to integration into Europe. In addition, as Anikó Imre explains, the Roma turn into a group against which Eastern Europeans affirm their whiteness. ${ }^{5}$ This conjuncture produces a situation where the Roma become the target of the sort of 'crude racism' that quite overtly and publicly resurrects the most bigoted tropes of colonialist and orientalist discourses.

In his reflections on 'racial neoliberalism,' David Theo Goldberg highlights a transformation in contemporary capitalism under which race has become "less explicit," and "less visible," because of circulating "more readily and openly in private spheres than in formal public ones." Similarly, in his widely cited book, Eduardo Bonilla-Silva describes contemporary U.S. racism as a "racism without racists" and a "color-blind racism" which operates much less overtly than the racism of the Jim Crow era. ${ }^{7}$ But Eastern European racism seems to have experienced no such shift. On the contrary, as the Bulgarian case demonstrates, racism's expressions are quite explicit, visible, and unabashedly crude. Consider the following few examples, among many others. In 2014, from the tribune of the Bulgarian parliament, Valeri Simeonov, MP and leader of the far-right National Front for Salvation of Bulgaria, referred to the Roma as "wild animals" and "arrogant, presumptuous, and ferocious humanoid apes." ${ }^{8}$ Not only were there no repercussions for his words but three years later he was appointed Vice Prime Minister of the coalition government in which his party participated. But right-wing populists are not the only ones who engage in such rhetoric. For example, Petar Moskov, former Health Minister from the pro-European, liberal Reformist Bloc, threatened in 2014 to ban the entry of ambulances into Roma ghettos and described their residents as "brutes" and "a population that has less understanding than wild animals." ${ }^{\text {W }}$ While this type of rhetoric by government officials resembles the racist discourses of colonialism and slavery, the Roma also encounter other forms of public racism evocative of Jim Crow era in the U.S. For example, on multiple occasions private swimming pools owners have refused admitting Roma to their premises. While this widespread practice rarely draws the attention of either the authorities or the media, the government's Commission Against Discrimination finally initiated an investigation of one such instance in 2019 after foreign tourists in Bulgaria circulated a photo of a sign above the entrance of a swimming pool in the popular Black Sea resort of Sunny Beach with the following (English) words on it: "Public Swimming Pool - Whites Only WHITE LIVES MATTER." 10 Even more telling about the explicit and obvious nature of Bulgarian racism in this case was the response on national television of Georgi Slavov, owner of the hotel and the swimming pool, and son of a Bulgarian mobster Stoil Slavov assassinated in 2004. While he denied that there had been such a sign at all, he also argued that he "regretted that he had not put one up," because if hotels existed "exclusively for gays, for families with kids, or families without kids, why should not there be a hotel for whites only!?"11

In short, racism in Bulgaria is anything but relegated to the private sphere alone. It explicitly reframes the fantasy of "catching up with the West" as a brutal return to the most notorious tropes and practices of colonialism and Jim Crow-style segregation. This, of course, is not to say that 'the West' has rid itself of racism while Eastern Europe remains one of its last bastions. However, while across the U.S., Britain, and Western Europe decades-long antiracist struggles have produced a situation in which overt instances of racism are met with critical scrutiny, resistance, and outright condemnation, in Bulgaria this is surely not the case. In fact, it is telling that frequent attacks against 'political correctness' in the country co-exist with little to no pushback against even the most outrageous expressions of racism and homophobia.

Prompted by this state of affairs, this article seeks to bring awareness to racism in Bulgaria through an analysis which examines its anti-Roma articulations on television. More particularly, I demonstrate the role that the televisual medium plays in framing and distributing historical colonialist tropes while highlighting the crudeness which distinguishes Bulgarian racism from the 'racial neoliberalism' theorized by the likes of Goldberg. At the same time, I also interrogate racism and its relationship to the neoliberal transformations in Southeastern Europe. I argue that shows such as NZ reinforce neoliberalism because despite their self-described 'socially engaged' approach, they fail to foreground the struggles of the Roma as part of the structural socio-economic failures of post-socialist capitalism, 
choosing to blame them instead for a range of (usually unrelated) social problems. Finally, even though the literature on the Roma is abundant, this article offers an insight, through its focus on television, into the underexamined topic of their racialization in media.

The first part of the article briefly delineates the contours of the debate on the suitability of the concept of race in an Eastern European context and its relationship to neoliberalism, while the second section explores the reasons behind selecting NZ as a primary source for this study. The rest of the paper includes three sections, each offering a detailed analysis of aspects of the show. I begin by discussing the racialization of Roma as a group allegedly external to the nation and NZ's attempt to control the discourse on Roma through its insistence on the value-laden misnomer 'tsigani.' Part of my goal here is to indicate the limitations of the concept of 'ethnicity' with respect to the Roma citizens of the country. I then examine the two major categories which most of NZ's episodes on the Roma fall into, namely their representation as criminals and as a demographic threat. Finally, I also explore the rare and limited redeeming features of $N Z$, including its few more positive episodes exposing the viewer to the difficult socio-economic conditions of Roma, along with even fewer ones when the Roma themselves speak, in their own voice, of the racism of the present and the socialism of the past.

\section{Race, Ethnicity, and Eastern European Scholarship}

While the literature on race and racism in Eastern Europe is growing, "there still remain few scholars actively researching in this area and resistance to centering race in SEES [Slavic and East European Studies] scholarship persists." 12 The reluctance to engage with questions of race originates from racism's tight historical connection to discourses of colonialism and imperialism from which Eastern Europe "continues to be excluded, and from which East European nationalisms are eager to exclude themselves."13 As a result, as Dušan Bjelić accurately observes, "the critical discourse on race barely exists and is historically and theoretically alien to postsocialist historiography on the grounds that Eastern Europe and the Balkans did not have and never were colonies."14 Indeed, distinguished historian of the Balkans, Maria Todorova, claims that the term 'colonial empire' is neither applicable to the Ottoman, Habsburg, or Romanov empires nor to the Soviet Union and its relationship with Eastern Europe. ${ }^{15}$ With regard to the Ottoman Empire and its five-centuries-long presence on the Balkans, Todorova notes that the empire lacked an "amelioration complex" and a "civilizing mission obsession comparable to the French or the English colonial project." 16 Nevertheless, some scholars have pushed against this erasure of race in the region. ${ }^{17}$ One reason for this push is that the absence of Eastern European overseas colonies or direct Western rule in the Balkans does not preclude the possibility of these countries' national identifications with whiteness. ${ }^{18}$ In fact, as Sunnie Rucker-Chang and Chelsi West Ohueri explain, "the false sense of racelessness" in the scholarship on this part of the world allows "whiteness to be unnamed and unquestioned" and prevents an understanding of the region as a place "shaped by global racialized processes that in turn produce varying forms of inequality, differences, and marginalization within the region." ${ }^{19}$ This article's focus on the racialization of the Roma in Bulgarian television validates Rucker-Chang and Ohueri's argument.

Drawing on Anthony Appiah's work, David Theo Goldberg defines "racialism" as "the view that groups of people are marked by certain generalizable visible and heritable traits" which predisposes racialists to think that "racial group members share not only traits but also behavioral dispositions and tendencies to think in certain ways those not so marked do not share." ${ }^{20}$ As I show in the analysis below, this type of racialism is clearly visible in the NZ Roma episodes in which skin color features as arguably the major and most visible marker of difference. Just as Appiah and Goldberg note, the show clearly posits that, along with physical and heritable traits such as skin color, the Roma also share particular, almost exclusively negative, cultural traits and disposition (such as propensity for stealing, having many children, living in dirt, etc.). However, drawing again on Goldberg and Appiah, racialism, which is clearly at play in NZ, does not amount to racism "if unaccompanied by consequential claims of inherent inequality or hierarchy." ${ }^{21}$ As my analysis of $N Z$ demonstrates, assumptions of superiority of ethnic Bulgarians over the Roma and their presumed inherent inferiority are abundant in the show. 
In sum, the analysis below demonstrates that racism figures overtly in Bulgarian society and ethnicity alone cannot sufficiently account for the differences between groups in the region. Maria Todorova defines ethnicity as "a commitment, ideology, or faith (often secular) based on a sense of (most often invented) kinship and common historical experience and, as a rule, on a community of language, religion, and custom." 22 This understanding of the concept implies selfcategorization while race is imposed by an outgroup and involves inferiorization. Thus, even though ethnicity offers a valuable perspective on difference, race provides another unique, and indispensable angle. At the same time, one must acknowledge that both of these categories remain insufficiently theorized when it comes to the Roma because, as Annabel Tremlett points out, there has been a lack of discussion in Romani studies on "theoretical approaches to terms such as 'ethnicity,' 'race,' and 'class."'23

Last but not least, the interrogation of race and racism in Eastern Europe is necessary because of the region's full integration into contemporary neoliberalism and as numerous scholars have shown, neoliberalism and racism are inseparable. ${ }^{24}$ David Harvey defines neoliberalism as "a class project" that "legitimized draconian policies designed to restore and consolidate capitalist class power." ${ }^{25}$ Somewhat similarly, Pierre Bourdieu characterizes neoliberalism as a "programme for destroying collective structures which may impede pure market logic." 26 Yet, its proponents have denied class-based and structural explanations of the deep inequalities and pauperization engendered by neoliberalism since the 1980s. Instead, they either minimize these negative outcomes or attribute them to insufficient entrepreneurship, lack of strong work ethic, dependence on the state, etc., on the part of those who are on the receiving end of neoliberal reforms. Similarly, racist discourse ignores economic and structural problems and faults alleged cultural and historical traits of minoritized and marginalized groups, such as laziness, parasitism, lack of discipline, etc., for social ills caused by contemporary unfettered capitalism. This dynamic is clearly visible in Eastern Europe and especially in Bulgaria whose economy constitutes a radical neoliberal experiment.

Bulgaria is both the poorest and most unequal member of the EU while it also features both the lowest flat income and corporate tax (10 percent) across Europe and globally. ${ }^{27}$ Poverty, crumbling healthcare and educational systems, and other negative consequences of neoliberalism fuel mass emigration and low birth rates. As a result, Bulgaria is the fastest shrinking country in the world with a population of 9 million in 1989 and under 7 million today. ${ }^{28}$ Nevertheless, the word 'neoliberalism' rarely appears in public discourse and the dire situation in the country is explained primarily through cultural and moral registers by all mainstream parties, including the Bulgarian Socialist Party (BSP), which was the major party in the coalition government that instituted the flat tax in 2007. But, as I show in this article, the reluctance to engage with the structural roots of Bulgaria's social problems is not only evident at the level of political parties and government institutions. Television and specifically shows such as NZ, which represent themselves as 'socially engaged,' consistently ignore the political and economic origins of the failures of neoliberalism. Instead, they point to marginalized groups such as the Roma as the cause of these failures. Because of the centrality of television to everyday life, it is important to examine how such racialized narratives sustain neoliberal discourse.

\section{No Man's Land and the Genre of Socially Engaged TV}

Despite the proliferation of digital technologies and spread of social media, according to the European Commission television remains the most used medium in Europe. ${ }^{29}$ Thus, even though the explosion of studies on the promotion of racism and extremist ideologies via social media is warranted, it is also important not to underestimate television. This is especially true in the post-socialist context where it was not until the late 2000 s that the Internet became more ubiquitous. In Bulgaria specifically, in the early 2000 s a mere $10 \%$ of the population had access to the Internet while only $3.1 \%$ used it daily ${ }^{30}$ and it was not until the mid-2010s that the Internet reached $50 \%$ penetration. ${ }^{31}$ 
A recent comprehensive study of media usage in Bulgaria confirmed that television remains the most consumed medium with $90 \%$ of the 1,200 respondents ages 18-65 claiming that they watch television at least once a day and $57 \%$ of them claiming that they watch television several times a day. The popularity of television is reflected not only by the large audience segment it attracts but also by the fact that it collects the lion's share of advertising revenues in Bulgarian media. ${ }^{32}$ Thus, the prominence of television warrants more scholarly focus on its role in racialization of the Roma.

NZ airs each Saturday on Nova, one of Bulgaria's two major commercial television channels; but its content is also available free of charge on the Bulgarian video platform VBOX7 and its last four seasons feature on YouTube as well. The focus of this study on NZ stems from two additional reasons. First, NZ is a part of a television genre very popular in Bulgaria. Unlike, reality (e.g., Big Brother, Survivor, Music Idol, etc.) and game shows (e.g., Who Wants to Be a Millionaire, Family Feuds, Deal or No Deal, etc.) which are franchises imported by Bulgarian television mainly from the West, this type of program is a local original product which does not copy an existing format created outside of Bulgaria. Referred to as zhiteysko rialiti (reality about everyday life) or dokumentalno realiti (documentary reality), this documentary genre is based on the stories of ordinary and marginalized people interviewed and filmed in their everyday settings, including psychiatric wards, prisons, homeless shelters, and ghettos. However, despite the reference to "reality," this genre has little in common with traditional reality formats with their scripted narrative, carefully screened participants, and staged setting, such as an island or a house. In fact, the reference appears more as a playful gesture which implies that the 'real' reality is in the immediate 'everyday life' of ordinary people and the daily problems they face. In addition, unlike most reality formats, this genre features an appeal for the viewer to show empathy and even to contribute to the solution of the social problem in focus. Thus, NZ boldly warns the viewer "Don't watch us if you don't care," while the script in the beginning of each episode echoes the alleged social engagement impetus of the show:

Some places are off the map, some memories can't be forgotten, some problems have no solution, some people do not matter. Nobody's places, nobody's memories, nobody's problems. There are stories which you will hear nowhere else but in 'No Man's Land.'

Besides the overall wide appeal of this genre, my selection of NZ specifically was prompted by its tested popularity. Produced by the pioneer in this genre, Teleman, a Bulgarian media production company which for the past seventeen years has created numerous documentary and reality series, crime, and talk shows, NZ aired first in 2014 and is currently in its seventh season. Few Bulgarian media products maintain such longevity because the contracts signed with the commercial television channels require consistently high audience ratings.

The main part of this study consists in a textual analysis of the first five seasons of the show (2014-2020) or 243 episodes ranging from 40-45 minutes. While I knew that NZ pays special attention to Roma themes, the fact that 62 episodes focused on Roma was a surprise, which further justifies the selection of NZ as a primary source for this article. But this study includes an analysis of all of NZ's episodes and not just the ones which focus on Roma. Even though this quadrupled the viewing and note-taking time necessary to complete this article, there are two reasons that justified this approach. First, it opened the opportunity to compare NZ's representations of Roma to those of other marginalized groups (e.g., LGBTQ community, Muslims, prisoners, the mentally ill, etc.) and second, it highlighted the different attitude of the show when it examined a social problem, such as crime, as pertaining to Roma as opposed to ethnic Bulgarians.

The goal of the analysis is not only to illuminate the racial dynamics on Bulgarian television, but also to interrogate the relationship of this medium to Roma - a theme that remains relatively unexplored despite the voluminous scholarship on European Roma. Furthermore, even when this relationship comes under scrutiny, scholars usually study reality TV formats and fiction films. ${ }^{33}$ Thus, the less explored genre of documentary television film opens another, less studied, perspective on media and racialization. 
M.Y. Marinos, Roma, Race and Socially Engaged Television on the Fringes of Europe

\section{$4 N Z$ and the Limits of Ethnicity}

One episode of $N Z$ focuses on the already well-publicized story of a scam in which Roma women enter fake marriages with non-EU citizens. Under this scheme, the Roma women receive a payment while the men, who are primarily from Pakistan, Bangladesh, and India, obtain the privilege to travel and live in the EU. The title of the episode, "The Third World Marries the Second One in Order to Reach the White One," embodies the racial anxieties which underpin the post-socialist condition. ${ }^{34}$ The Second World, to which Bulgaria belongs, features as a midpoint between the white EU and the black "Third World." In this worldview Bulgaria features as a peripheral entry point of the EU but it is not quite as white as Western Europe. Thus, this episode is reflective of the perennial feelings of inferiority and backwardness of Eastern Europeans, which throw into question their whiteness.

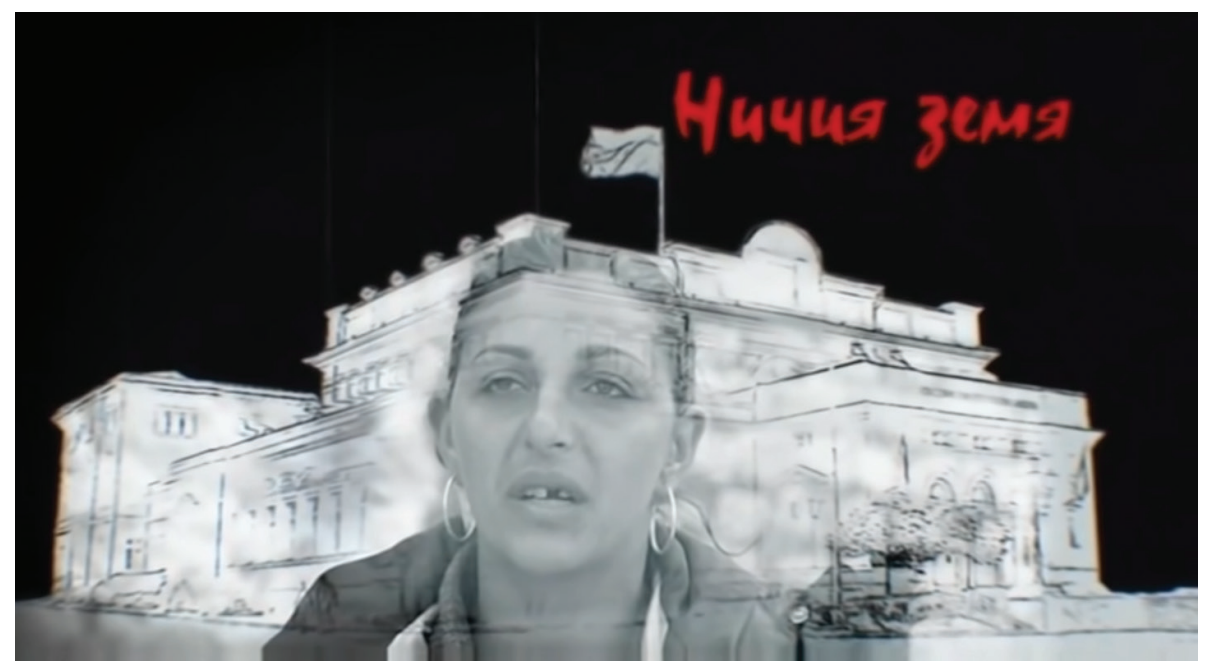

Video 1. Nichia Zemia, "The Third World Marries the Second One in Order to Reach the White One," May $25,2019$.

While these anxieties exist across Eastern Europe, they only intensify along Europe's border with Asia and the Middle East. Furthermore, besides Bulgaria's location as the easternmost member of the EU, its status as its most impoverished and corrupt member further fuels these insecurities. ${ }^{35}$ Yet, NZ never explores the socio-economic structural conditions of Bulgaria's social problems, but instead frames the Roma as the impediment to Bulgaria's 'return to Europe.' Thus, in the episode about fake marriages, the narrator reminds viewers that this show airs a day before the elections for Members of the European Parliament and clearly suggests that these illiterate Roma women denigrate Bulgaria's image in the EU. This type of narrative, which frames Roma as backward and a hindrance to Bulgaria's integration into the white West while failing to interrogate the neoliberal structural causes of the extreme rural poverty they live in, emerges frequently in NZ.

This type of racialization, which inferiorizes the Roma and turns them into an obstacle to the European integration of Eastern European countries, plays a part in a dynamic typical of racism more broadly - the treatment of a social group as external to the nation. While some consider the Roma as an 'internal Other,' that is, as a social group against which the majority population affirms its difference but recognizes it as a part of the geographic territory of the nation state, their representation as a 'problem' that faces the EU transforms the Roma into an 'external Other.' Thus, as Etienne Balibar rightly notes, the view of the Roma as a "problem" is "a preliminary step" in their "new racialization" because it "puts them in the same category as the 'migrants' of extra-communitarian origin..."36 Similarly, Paloma Gay y Blasco claims that "across varied representational arenas Roma are consistently portrayed as outside the nation, as its objects - to be managed and controlled - rather than its subjects." ${ }^{37}$ 


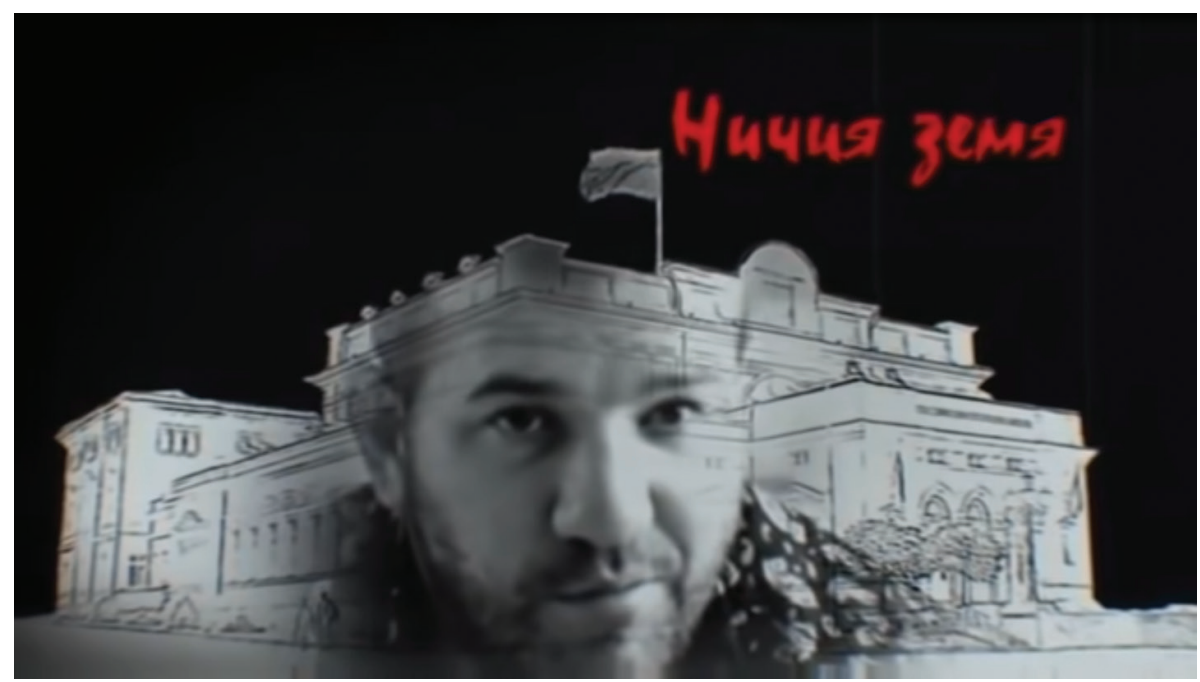

Video 2. Nichia Zemia, "A Hero of Our Time," March 4, 2017.

Several NZ episodes on the Roma confirm this logic as they portray the Roma as external to the nation state. This process comes in full display in an NZ episode on Dinko Valev, "Bulgaria's vigilante migrant hunter" who became an instant celebrity after an avalanche of media coverage glorified his "capturing" of Syrian refugees in the forests on Bulgaria's border with Turkey. ${ }^{38} \mathrm{NZ}$ joined the long line of media outlets which provided him with a platform, rebroadcasting a cell phone video of the moment when he and his friends apprehended a group of Syrians. In this video Valev refers to them as "tsigancheta" or "little gypsies." In this episode, entitled "A Hero of Our Time," Valev claims that the Roma and the "lice-infested Taliban" get more support from the state than Bulgaria's pensioners and further compares the Roma to the "Mexican scourge" in the U.S. ${ }^{39}$ This type of rhetoric, which transforms Bulgarian Roma citizens into an external group equivalent to refugees and even the Taliban predates the war in Syria. A notorious example of this discourse was a controversial 2007 video which showed Bulgarian soldiers who were part of the "Coalition of the Willing" referring to Iraqi children lined up for water as "mangali"40 and "tsigani."

The racialized representation of the Roma as external Other becomes especially visible when one compares these episodes to ones that deal with other marginalized groups. For instance, there is a sharp contrast in how NZ discusses the LGBTQ community. Indeed, the four episodes which deal with this theme are progressive and challenge the viewers' beliefs in a country with high levels of homophobia. The narrator asks the audience "to accept the Other" and concludes one of the episodes sarcastically by saying that "homosexuality is not contagious but the hatred to those who are different is." ${ }^{41}$ Such calls for acceptance are entirely absent in NZ's episodes on the Roma, which is another indication of how deeply ingrained racism in Bulgaria is.

Another feature of $N Z$, and racism in general, is the desire to control and exert power over racialized groups considered external to the nation. In respect to the Roma, a prime example of this situation includes the struggle to control their name because "to control what a group is called is to control what is thought about that group as well as what that group thinks about itself." ${ }^{2}$ NZ's incessant reference to Roma as "tsigani," which when deployed by an ethnic Bulgarian is rarely value-neutral, illustrates the power dynamics which undergird naming.

In 1971, the International Congress of Roma adopted the name "Roma," which translates from the Romani languages as "people," in order to counter the negative references to its constituency. But the resistance to this name by the dominant majority remains strong. In fact, in Romania this opposition took a dramatic turn after the government outlawed the use of the word "Roma" due to its proximity to "Romanian." ${ }^{43}$ In Bulgaria, the resistance to this term is also widespread. The NZ journalists almost always refer to Roma as "tsigani." Furthermore, I recorded seventeen 
occasions in which NZ's journalists were openly hostile to the term "Roma" and challenged its use in the course of the show. In seven of these cases, the journalists interrupted an interviewee who used it. For example, an ethnic Bulgarian woman describes the situation of a local school and notes that most of the pupils were "Roma." At this point, the interviewer interrupts her in mid-sentence asking, "why do you call them Roma?" to which the woman replies that she felt obliged to do so because of the camera otherwise she considers them "proper tsigani." ${ }^{\text {4 }}$ On these occasions, the desire to control the discourse precipitates the abandonment of basic professional standards as the journalists interrupt and correct interviewees and deviate from the topic of discussion. Clearly annoyed by the word "Roma," they turn into censors who react swiftly once they hear the word. In this respect, television plays a reactionary role as it insists on the use of an offensive term when interviewees use a value-neutral one.

Another, equally aggressive form of control over naming occurs at the level of narration. I counted four cases in which the narrator mocks the use of the term "Roma." For instance, in the conclusion of one episode he notes with irony, "Tsiganite... pardon me! 'the Roma'..." while in another episode he clarifies that he only uses the term "Roma" in order to avoid the ire of human rights organizations..$^{45} \mathrm{~A}$ less disruptive way of control occurs when the journalist asks a Roma interviewee whether they find the word 'tsigani' offensive. In all these four cases the Roma people reply in the negative, which frees the journalist from the responsibility to use the term 'Roma.' The remaining cases in which the term "Roma" takes center stage are the two occasions when Roma interviewees confronted the journalists' use of the term 'tsigani.' In one of these episodes a young Roma man politely notes, "Just to correct you, we are not 'tsigani,' we are 'Roma."' 46 The other confrontation occurs when a Roma worker in a junkyard tells the journalist that he finds her use of the term 'tsigani' offensive. In an inane response which makes the journalist appear even more racist, she jokes that she is uncertain of the Roma man's identity because she thought that his dark skin color was the result of the dirty job he held at the junkyard. ${ }^{47}$

\section{Roma as Criminals and a Demographic Threat}

As a part of the textual analysis of NZ I divided the representations of the Roma into two major categories. Their portrayal as criminals and as a demographic threat dominate NZ's episodes. Out of the 62 episodes on the Roma, eighteen revolved around the topic of Roma birth rates and teenaged Roma mothers, which the narrator often describes as a "ticking demographic bomb." This category also includes a strong emphasis on the threat posed by the growth of the Roma population to the welfare state. The second most common theme is the representation of the Roma as criminals, with sixteen episodes fitting in this category. Most of them focus on 'petty' or 'everyday crime' (bitova prestapnost), which is a term that has operated as a synonym to 'Roma thefts' since 1989.

There is frequent overlap between these two dominant narratives; and on three occasions I was unable to assign the episodes to just one of the categories. For example, one of these episodes focused on Roma female prisoners who gave birth while in prison. NZ emphasized both the women's fertility and their crimes captured perfectly by the narrators' concluding remarks that, "regrettably," the hospital in which they gave birth could not treat "proclivity for stealing and new pregnancies." 48 Thus, I included this and two additional episodes that fuse these two narratives in both categories. In sum, a total of thirty-one episodes, or exactly one half of all episodes on the Roma, painted an entirely negative picture focused on criminality and the threat they pose to the purity of the Bulgarian nation.

\subsection{Roma as a Demographic Threat}

The speculation that Roma birth rates threaten the homogeneity of the nation is not unique to Bulgaria. But, as I mentioned above, the anxieties stoked by this discourse only intensify with Bulgaria's very real depopulation problem 
M.Y. Marinos, Roma, Race and Socially Engaged Television on the Fringes of Europe

which makes Bulgaria the fastest shrinking country in the world. ${ }^{49}$ The racialization in NZ's eighteen episodes on Roma birth rates demonstrates this dynamic.

Two NZ episodes focus on the illicit trade of Bulgarian Roma babies in Greece. Under this scheme, pregnant Roma women are trafficked to Bulgaria's southern neighbor, where they give birth. Through a corrupt system that involves Greek government officials and doctors the newborns are then sold to Greek parents. In this episode NZ relies heavily on a disenchanted Bulgarian human trafficker who explains that the cost of a baby depends on its race. Most of the babies, he notes, are "black" and cost around $€ 6,000$. In the rare cases when the mother is not Roma and the baby is "white" (belichko), the price could reach as high as $€ 18,000$. Through a hidden camera NZ captures a conversation with a human trafficker who seeks buyers for a newborn he describes as "a very beautiful white baby" with a "white" Turkish-Bulgarian woman as a mother. ${ }^{50}$ These episodes demonstrate that the racialization of the Roma distinguishes them not only from ethnic Bulgarians but also from the Turkish minority in Bulgaria.

NZ's concern with Roma birthrates also includes a focus on very young mothers. There are two episodes which explore the cases of twelve-year-old Roma mothers and one episode about a fourteen-year-old who had given birth to Siamese twins. ${ }^{51}$ In addition to its interest in young Roma mothers, NZ also seeks out Roma women with many children. These episodes portray the Roma as a group that procreates in order to avoid work and instead depends on the state. Indeed, the representation of Roma as a burden to the taxpayers is a recurring theme in the show. An especially revealing example of this dynamic is an episode that follows up on a conflict between a social worker and a Roma mother of five. The two women engaged in a fist fight after the Roma woman received a rejection for a one-time aid of 250 leva $(€ 125)$ for her first-grader son. NZ interviews primarily the social worker featured as the victim in this dispute. She describes the Roma woman's behavior as "animal-like" and claims that the state does its best to help the Roma, but they refuse to integrate. The journalist remains firmly partial to the social worker's side of the story while the narrator concludes that those who try to help the Roma get beaten as a token of appreciation. ${ }^{52}$

The alarmist tone of NZ's episodes on Roma childbirth rates stands in stark contrast with the two episodes about ethnic Bulgarian families with multiple children. NZ pursued these stories because, in both cases, the state agency for the protection of children took all or some of the children because of their living conditions.

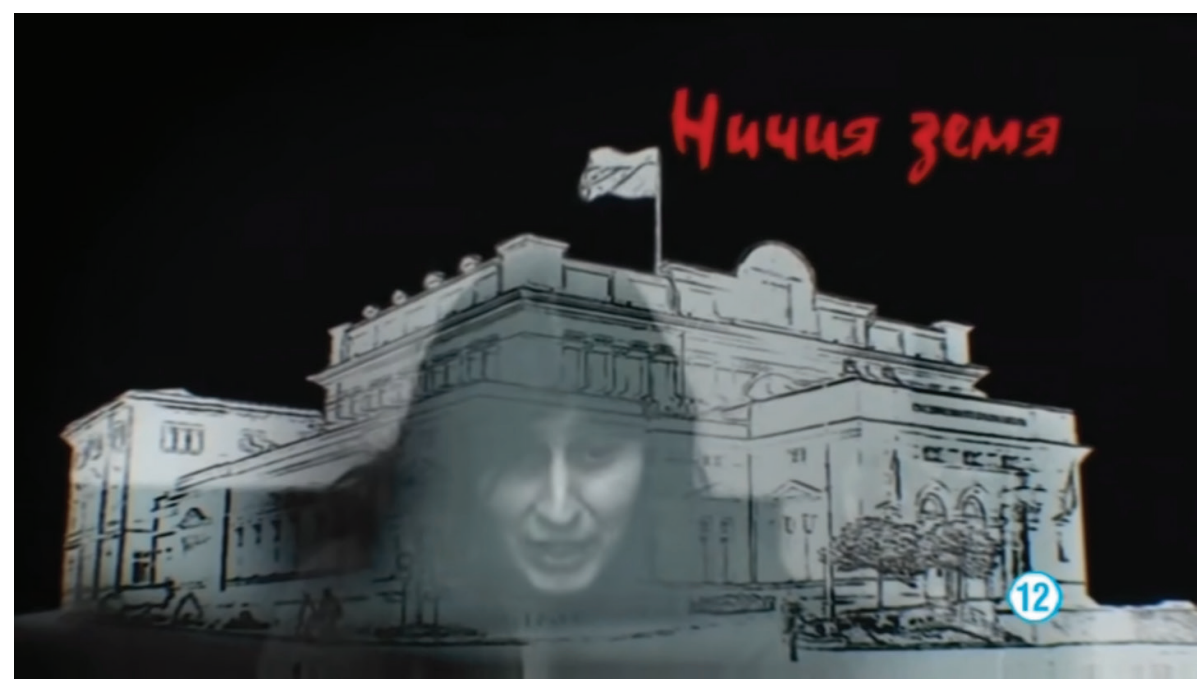

Video 3. Nichia Zemia, "The Disappearing Nation,” April 28, 2018.

One of the episodes focuses on a family with thirteen children-a record number which, according to the social worker interviewed in this show, remains unmatched "even" in Roma families. The state intervened after two of the children 
died-one due to malnourishment and insufficient care and the other one after a tragic incident in which a hot stove crushed him to death. In response, the authorities placed the remaining children into foster families. In contrast to the episode which followed up on the fist fight between the Roma mother and the social worker, here the social worker is a villain, and the journalist is hostile to her. In addition, melancholic music and camera shots of empty children's rooms bolster the emotional appeal of the story. The episode also highlights the racial dynamics that underpin demographic issues. When asked why the state intervened, the parents engage in a conspiracy theory according to which the authorities took the children because they were "very beautiful and white." While it remains unclear what the state gains from these "white and beautiful" children, the implication is that it would not have intervened if they were darkskinned Roma children. ${ }^{53}$

The other episode which also focuses on an ethnic Bulgarian family with many children is about a single father of nine. The squalid living condition and perceived danger to the children led to the placement of three of the youngest children into a foster family. Once again, in contrast to the episodes on Roma families with multiple children, in this episode the journalists side with the family. The question, "Why did you have so many children?", asked to every Roma woman with many children on the show, is absent. In fact, after the father explains that the living conditions deteriorated after the mother left the family, the interviewer expresses surprise that they had separated since "nine children are a proof that there was a lot of love in this home." Furthermore, at the end of the episode the narrator urges the viewer not to judge the father for having too many children. He quotes Martin Luther King on the importance of the right to freedom, which according to the narrator, includes the freedom to have as many children as one wants. This conclusion is in stark contrast to the alarmist tone of the episodes on Roma families with many children. ${ }^{54}$

There is room for criticism of marriages of minors, arranged marriages, family planning, domestic violence, and virginity tests in Roma communities. ${ }^{55}$ In fact, as the Roma feminist activist and lawyer Alexandra Oprea argues, the anti-racist struggles of the Roma should not trump the fight against patriarchy. But the rhetoric on these issues advanced by television programs such as NZ, derives from a racist and non-feminist perspective. What makes matters worse is that the mobilization of the alarmist discourse on Roma childbirth rates has been at the core of the post-socialist neoliberal assault on the welfare state.

The belief that Roma families sustain themselves through welfare payments which increase with each subsequent child remains a powerful myth. According to this narrative, most teenage Roma girls already have several children in order to claim social benefits. ${ }^{56}$ However, according to the Bulgarian Statistical Institute, in 2011 there were only 273 women (128 of them Roma) below the age of 19 who had three children. Furthermore, the support for children in Bulgaria is miniscule and only families with an income of less than 400 leva (€200) per month are eligible for these benefits. If they qualify, the family receives 37-leva $(€ 18.50)$ monthly contribution for their first child, 48 leva for the second (€24), 45 leva (€22.50) for the third, 10 leva (€5) for the fourth and 20 leva (€10) for each subsequent child. Lastly, these benefits also depend on an additional set of criteria including the child's regular attendance in school or kindergarten and a record of vaccinations. ${ }^{57}$

The racism against Roma and their transformation into a demographic threat are at the roots of the systematic reduction of the welfare benefits for all children after 1989. As it is always the case in neoliberal discourse, impoverishment is explained as a moral and personal failure rather than as the result of structural forces. This creates a situation in which the state's efforts to alleviate social suffering appear as a misguided squandering of public resources, which benefits irresponsible and immoral populations who are the only ones to blame for their misfortunes. Successive post-1989 Bulgarian governments, including the ones headed by the BSP, used racist pretexts targeting the Roma to drastically limit the social benefits for children and retrench the welfare state in general. ${ }^{58}$ The only beneficiaries of these politics are the wealthiest Bulgarian citizens and companies who benefit from the lowest tax burden in the EU. With its disregard of the socio-economic conditions of the Roma and their racialization, $N Z$ reinforces neoliberalism despite the fact that the show's producers describe it as a "socially engaged" media product which challenges the status quo. 
M.Y. Marinos, Roma, Race and Socially Engaged Television on the Fringes of Europe

\subsection{Roma as Criminals}

The second major category of Roma representations in NZ is their portrayal as criminals. Most of the sixteen episodes in this group deal with 'everyday crimes' or 'petty crime' (bitova prestapnost). I prefer the translation 'everyday crime' rather than 'petty crime' because the latter alludes to something minor. But these types of crimes receive much attention and are regarded as severe violations while the term 'everyday crime' features as a synonym to 'Roma crimes.'

$N Z$ pays special attention to rural areas, which have suffered the most from the neoliberalization of the economy. The show frequently visits Bulgaria's northeast region, which is the poorest region in the EU with a GDP per capita at $29 \%$ of EU's average. ${ }^{59}$ The post-1989 elimination of the factories and plants in this area and the decimation of the agricultural cooperatives (TKZS) resulted in mass unemployment. As a result, many emigrated, mostly to Spain, Greece, and Great Britain, mostly as agricultural workers, in some cases leaving entire villages depopulated. Because of the lack of opportunities, few young people remain while their elderly parents keep these once thriving villages and towns alive. Besides the mostly retired population, the northeast region is also home to Roma minorities. Previously employed in the state's agricultural sector, many of them now live in nineteenth-century conditions with extreme poverty and no indoor plumbing or hot water. While the conditions in Bulgaria are especially dire, sociologist Gail Kligman shows that the situation is similar across the region.

Roma who had worked in agriculture before 1989 were especially hard hit by privatization and the redistribution of land. Having provided adequately and even well for their families during socialism, these Roma "peasants" found themselves jobless and landless and, again, with few options open to them. ${ }^{60}$

But, following the familiar neoliberal script, $N Z$ hardly addresses the socio-economic problems of rural Roma and instead exploits the tensions between them and the elderly residents of northeast Bulgaria. Represented as thieves, they feature as the main enemy of their older ethnic Bulgarian neighbors. One of these episodes focuses on a village which had 1800 people before 1989 but afterwards shrank to 58 mostly elderly ethnic Bulgarian residents and approximately 250 Roma. As with other episodes on this theme, this one also features distraught elderly people sobbing about stolen hens, jars with pickled vegetables, potatoes, and gardening tools, while one of them describes the Roma as "pirates" who pillage the village. ${ }^{61} \mathrm{NZ}$, however, rarely includes the voices of Roma in these areas and frames them as people who resort to crimes because of laziness. Thus, the narrator concludes an episode on a village located in Bulgaria's rose producing region of Kazanlak by saying: "We told you a story about hunger as an excuse to terrorize and steal and a story about a village which should have roses but instead has Roma." 62 But, as Kligman explains, such discourse features an obvious contradiction because it frames Roma as unwilling to work even though "during the socialist period, Roma regularly worked in state-run agriculture and industry, usually in un- or low-skilled, labor intensive jobs." 63

The sole episode about a petty crime committed by an ethnic Bulgarian against a Roma family reveals the deep contrast with the multitude of episodes about Roma everyday crimes. In this case an ethnic Bulgarian man stole the winter supply of sudjuk ${ }^{64}$ of a Roma couple who had just returned to their Bulgarian village after a long period of agricultural work in Spain. But this episode lacks melancholic music, sobbing pensioners, and stern interviewers. Instead, joyful Goran Bregović's songs and jokes accompany the story as the narrator ends with "we had a good laugh today" - a radically different conclusion than his gloomy and alarmist statements in the episodes about crimes allegedly committed by Roma. ${ }^{65}$

Besides everyday crimes, NZ also exploits more serious offences, such as the murders of ethnic Bulgarian women by Roma men. Although there are only two such episodes, their emotional charge is significant. While these are very rare cases, the narrator of NZ frames these tragic events as a frequent occurrence: "Recently in every sinister story that involves a beautiful Bulgarian girl there is a tsiganin involved-scary but accurate picture of our demographic condition." 66 One of these episodes focuses on the already well-publicized brutal murder of Veronika Zdravkova. NZ visits the home of 
her grieving parents in what is a profoundly grim episode. At one point, in front of the camera Veronika's father opens a parcel mailed to him by her as a birthday gift shortly before her murder. The scene is deeply moving as everybody present breaks down into inconsolable bawling. In fact, I found this shot by far the saddest moment of all the other mostly gloomy 243 episodes of $N Z$. However, its ending is highly problematic as it mobilizes the sadness into a racist direction. In a shot by Veronika's grave, her father states that he "loathes" all Roma because they are "insolent," give birth to "countless number of children," and drain the social benefits of the state. He also claims that while their human rights are respected, his daughter's human right to live was not and for this reason he wants to "run them over" with his car wherever he meets them. In response to his threats, the journalist warns him that the Roma are "vengeful" so he should speak more cautiously. ${ }^{67}$

This type of media coverage is especially dangerous in Bulgaria, where the 2010s saw several pogrom-like events in the villages of Katunitsta (2011), Garmen (2015), Sofia's neighborhood of Orlandovtsi (2015), and the town of Asenovgrad (2017), where intoxicated football hooligans and far-right groups joined local protests against Roma communities in response to criminal incidents. Bulgarian mass media's overemphasis on Roma criminality certainly played a role in these tensions. NZ, specifically, does little to challenge the stereotype of Roma as criminals and the episodes on this theme expose the crude racism of this discourse.

As it is the case with the representation of Roma as a demographic threat, their portrayal as criminals who steal and rape and murder white women, are tropes familiar from racial demonization rooted in orientalist and colonialist narratives. Looked at from this angle, the post-1989 main slogan of "catching up with the West" gains a different meaning as it appears that Eastern Europe has indeed caught up with the racist legacy of Europe and North America. But there is also one major difference. While for the most part, racist television content is under constant public scrutiny in the West, the complete absence of criticism of the frequency and lack of subtlety in the deployment of racist tropes in NZ, and many other similar Bulgarian shows, demonstrates how highly normalized this discourse is.

\section{NZ's Redeeming Features}

Most of NZ's episodes on Roma pursue stories that paint a negative image of them. Yet not all of $N Z$ is damaging and the show has some limited redeeming features which are, however, far outweighed by its primarily nationalist content. I assigned ten of NZ's episodes to a category which portrays successful, hard-working, and honest personalities. Nevertheless, even these stories require a significant qualification because they frame the 'good Roma' as an exception. Here, the centrality of NZ narrators' conservative framing of the episodes becomes most apparent. For example, one episode interviews a Roma couple introduced by the narrator as "tsigani who would surprise you: hard-working and robbed." Radka and Metodi had migrated to Cyprus, where they worked for a decade, leaving behind their child to be raised by the grandparents. The couple describes a life of hard work and deprivations as well as their untimely return to Bulgaria due to Metodi's diagnosis of colon cancer. The situation turns from bad to worse when a burglar breaks into their apartment and steals the money they had saved for Metodi's surgery. The episode is an excellent depiction of the difficulties and discrimination faced by Roma people. Yet, the narrator's reminders that "tsigani also get robbed" also affirms the negative stereotypes of Roma people. ${ }^{68}$ These interventions by the narrator permeate the other episodes about 'good Roma.' For instance, a Roma family who had joined an American Evangelical church features as "unusual tsigani" because they chose "to follow God's laws rather than steal." ${ }^{\prime 9}$ Similarly, another episode introduces the viewer to "an exceptionally clean" Roma house. ${ }^{70}$

The narrators' influence derives not only from their control of the introduction and the conclusion of the show, but also from the authoritative quality of their voice. In its first three seasons NZ's narrator is Manol Kakov, one of the most recognized voices of Bulgarian television. On November 10, 1989, Kakov became the first journalist who read the news of the removal of Todor Zhivkov, Bulgaria's long-term General Secretary of the Bulgarian Communist Party. Kakov was also the narrator of many Bulgarian documentary films, emblematic television shows as well as National 
M.Y. Marinos, Roma, Race and Socially Engaged Television on the Fringes of Europe

Geographic documentaries. Another narrator of NZ whose voice also radiates authority is Daniela Trencheva, who worked for years as a newscaster in Nova. Thus, the power of the narrator's voice also contributes to the negative framing of the episodes about 'good Roma.' Nevertheless, these episodes contain some redeeming features including their exposure of the adversities faced by Roma people. For example, an episode about a twelve-year-old, talented, cello player shows that she shares a single room with her blind father in the city of Sliven's Roma ghetto. They lack hot water, inside plumbing, and depend on the father's 255 leva (€127) disability pension. Svetlozar Kirilov, a Bulgarian scholar who studies mass media's representation of Roma people, argues that it is precisely such media content that could trigger emphatic response in ethnic Bulgarians, most of whom have little exposure to the difficult living situation of the Roma. ${ }^{71}$

Despite their positive content, these episodes racialize Roma and fail to situate the stories within the radical neoliberal transformation of the Bulgarian economy. Somewhat of an exception to this trend is an episode about rose harvesters in Bulgaria's Rose Valley, the region that produces half of the world's rose oil. Even though like the rest of the series, this episode omits any mention of the word capitalism, it offers a critical portrait of the neoliberalization of the economy, including the proliferation of underpaid work, the decimation of adequate education and healthcare, and mass migration of entire communities to Western Europe. The Bulgarian rose is not only the country's most recognized export, but the symbol of the rose is also intertwined with national history and it features as the official tourist logo of Bulgaria. In the beginning of this episode, replete with symbolism, NZ shows a picture of the socialistera lokum (Turkish Delight) box, familiar to most Bulgarians, which features the image of a female ethnic Bulgarian rose harvester. It also includes newsreel footage from socialism, which shows smiling, red-cheeked women picking roses. The main goal of the episode, however, is to find out who harvests the roses today. What follows parallels Friedrich Engels' descriptions of the $19^{\text {th }}$-century conditions of the English working class. ${ }^{72}$

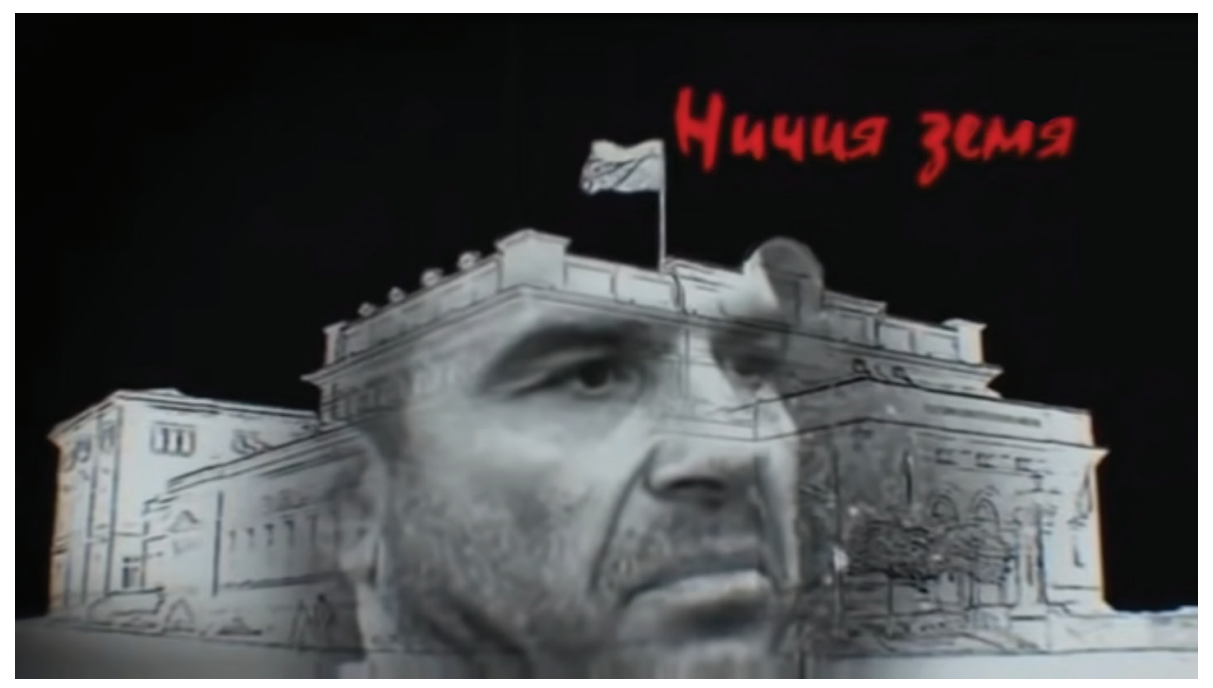

Video 4. Nichia Zemia, “The Queen of the Roses," July 11, 2016.

Entitled "The Queen of the Roses," it zooms in on a 12-year-old Roma child laborer, who works in the rose fields sick with pneumonia. Another Roma worker in this extremely labor-intensive industry shares that she has resumed work shortly after a stroke. As such, the episode is a microcosm of the cruelty of neoliberalism. The low salaries and difficult working conditions in Bulgaria had led to the emigration of the white and red-cheeked harvesters to Western Europe, where they provide cheap labor. In turn, this has resulted in a shortage of agricultural workers in Bulgaria's most lucrative industry, only partially alleviated by an underclass of Roma child laborers and sick Roma women. In yet another proof of the importance of race in this show, the narrator concludes that the harvesters' belonging to a "low social layer" leaves a "dark mark" on the Bulgarian rose while the entire show revolves around the disappearance of 
M.Y. Marinos, Roma, Race and Socially Engaged Television on the Fringes of Europe

the ethnic Bulgarian harvesters and their replacement with Roma women. ${ }^{73}$ While the episode follows the overall racist script of $N Z$, its exposure of the horrid work conditions of Roma rose harvesters is not seen often on Bulgarian television.

Besides the exposure to the difficult conditions of the Roma, an additional redeeming feature of these episodes is their occasional inclusion of Roma voices. This is significant because their speech is most often excluded as they have "no part to play in talk shows, soap operas, or commercials, where some of the dominant cultural values of the nation are reflected, created, and confirmed."74 Even though their opinions encounter the slanted questions of the journalists and the conservative framing of the narrator, their voices are a meaningful part of the show. For example, in one of these episodes NZ follows a group of Roma garbage collectors in downtown Sofia. They recount numerous stories of racial abuse as well as an attack by an intoxicated group of ethnic Bulgarians, which left one of their colleagues stabbed with a knife. Despite the patronizing assurances of the interviewer, they insist that the discrimination they experience shows that they are not considered a part of Bulgarian society. ${ }^{75}$

Finally, the inclusion of Roma voices also brings to the fore narratives in which the older generation of Roma speak with open admiration about socialism and its policies of full employment, free education, and lower levels of racial discrimination before 1989. For example, in an episode about a gynecologist who works in one of Sofia's Roma ghettos, the doctor states "there was no hunger back then [during socialism]"; but after 1989 he treats starving pregnant Roma women whose diet is only bread and unripe plums (djanki). He also adds that during socialism all Roma could read and write but this is no longer the case. ${ }^{76}$ These types of stories are a significant break from the hegemonic anti-communist discourse. Furthermore, this attitude appears in episodes that are not about Roma people as well. For instance, NZ includes the story of an Afro-Cuban who arrived in Bulgaria to study as a part of the socialist internationalist exchanges and never left the country. In this interview he praises Cuba's egalitarianism, describes Che Guevara as a hero, identifies himself as a communist, and concludes that Bulgaria's most pressing problem are "rich people."77

\section{Conclusion}

The analysis of NZ's episodes demonstrates that racism in Bulgaria is overt and appears forcefully on mainstream media outlets, such as Nova, which claims to be the most watched television channel in Bulgaria. Thus, the scholarship that notes a shift in contemporary U.S. and Western Europe, where racism operates more openly in the private than in formal public sphere, does not seem applicable to the Eastern European context. In fact, in Bulgaria the fantasy of "catching up with the West" appears as a return to the most notorious tropes and practices of colonialism, orientalism, and Jim Crow-style segregation. In addition, in contrast to descriptions of contemporary racism in the U.S. as "color-blind," advanced by scholars such as Eduardo Bonilla-Silva, NZ shows abundantly clear that skin color plays a crucial role in racialization. It remains a central vector of distinction between the Roma and ethnic Bulgarians through which the latter affirm their whiteness.

The analysis of $N Z$ also shows that it is important to place processes of racialization within the context of contemporary neoliberalism in which Eastern Europe is fully integrated. I do not claim that neoliberalism invents racism because the racial tropes $N Z$ engages predate contemporary capitalism. But clearly, the effects of neoliberalism, including the retrenchment of the welfare state and the shift of the tax burden from the richest to the poorest through the implementation of flat taxes, intensify discourses that represent the Roma as parasites who leech on the ever so limited collective resources. Similarly, their portrayals as a threat to the nation's homogeneity are also more appealing in places such as Bulgaria, where the demographic collapse triggered by neoliberalism is the most extreme in the world. But it is also important to demonstrate the role television plays in advancing the goals of neoliberalism through ignoring the socio-economic roots of the ongoing deterioration of the living conditions of large social groups in Eastern Europe, including the Roma. As Nando Sigona and Nihdi Trehan point out, "the profound shifts in economic policy towards 
neoliberal market principles in the 1990s in the former socialist countries of Europe (in some cases, a 'shock therapy') resulted in catastrophic unemployment for many Roma." ${ }^{\prime 8}$ Yet, even shows such as NZ, which allege that they are socially engaged and committed to persuading the viewer "to care," fail to analyze these circumstances and instead racialize the Roma through the crudest forms of colonialist and imperialist discourses.

\section{Acknowledgement}

The author would like to thank Nikolay Karkov for his comments and helpful suggestions with this text.

\section{Notes}

1. Nichia Zemia [No Man's Land], ep. 40, dir. by Nikolay Rusakiev, aired March 28, 2015, Teleman Productions, 2014-2021. In this article I use the Bulgarian term 'tsigani' which translates as 'gypsies.' However, 'gypsies' does not always imply a negative meaning, but if used by ethnic Bulgarians 'tsigani' almost always has a derogatory connotation.

2. NZ, ep. 181, December 15, 2018.

3. NZ, ep. 184, January 12, 2019.

4. See Dušan Bjelić, "Toward a Genealogy of the Balkan Discourses on Race," Interventions: International Journal of Postcolonial Studies 20, no. 6 (2018): 906-929; Anikó Imre, "Whiteness in Post-Socialist Eastern Europe: The Time of the Gypsies, the End of Race," in Postcolonial Whiteness: A Critical Reader on Race and Empires, ed. Alfred López (New York: State University of New York, 2005), 79-102; Catherine Baker, "Postcoloniality Without Race? Racial Exceptionalism and Southeast European Cultural Studies," Interventions: International Journal of Postcolonial Studies 20, no. 6 (2018): 759-784.

5. Anikó Imre, "Love to Hate: National Celebrity and Racial Intimacy on Reality TV in the New Europe," Television \& New Media 16, no. 2 (2015): 103.

6. David Theo Goldberg, The Threat of Race: Reflections on Racial Neoliberalism (Malden, MA: Wiley-Blackwell, 2009$), 356$.

7. Eduardo Bonilla-Silva, Racism without Racists: Color-Blind Racism and the Persistence of Racial Inequality in America (4 ${ }^{\text {th }}$ ed., Lanham: Rowman \& Littlefield Publishers, 2014).

8. Jana Tsoneva, "Bulgaria's Creeping Apartheid Part I: Mobilizing Racism to Shrink the Social State," Lefteast, January 5, 2015, https://lefteast.org/bulgarias-creeping-apartheid-i-mobilizing-racism-to-shrink-the-social-state/

9. Bulgarian Helsinki Committee, "Bulgarian Ambulances Will Enter Roma Neighborhoods Only after Safety Is Guaranteed," Liberties, December 23, 2014, https://www.liberties.eu/en/stories/restricted-access-to-emergency-aid-for-roma-inbulgaria/2737

10. Tatyana Dimitrova, "Komisiata za Diskriminacia se Zahvashta s Hotel s Basein 'Samo za Beli” [The Commission Against Discrimination will Investigate a Hotel with a Pool for 'Whites Only'], Dnevnik, September 9, 2020, https://www.dnevnik.bg/ bulgaria/2020/09/09/4111460_komisiiata_za_diskriminaciia_se_zahvashta_s_hotel/

11. Ibid.

12. Sunnie Rucker-Chang and Chelsi West Ohueri, "A Moment of Reckoning: Transcending Bias, Engaging Race and Racial Formations in Slavic and East European Studies," Slavic Review 80, no. 2 (Summer 2021): 220-221.

13. Imre, "Whiteness in Post-Socialist Eastern Europe," 83.

14. Bjelić, "Toward a Genealogy," 906.

15. Maria Todorova, "Balkanism and Postcolonialism, or On the Beauty of the Airplane View," in In Marx's Shadow, eds. Costica Bradatan and Serguei Oushakine (New York: Lexington Books, 2010), 178.

16. Ibid., 179.

17. See Dušan Bjelić, "Bulgaria's Zionism, The Colonization of Palestine and The Question of Balkan Postcoloniality," Interventions: International Journal of Postcolonial Studies 19, no. 2 (2016): 1-20; Sharad Chari and Katherine Verdery, "Thinking Between the Posts: Postcolonialism, Postsocialism, and Ethnography after the Cold War," Comparative Studies in Society and History 51, no. 1 (2009): 6-34; Anikó Imre, "Postcolonial Media Studies in Postsocialist Europe," boundary 241 , no. 1 (2014): 113-134.

18. Imre, "Whiteness in Post-Socialist Eastern Europe," 83 and Baker, "Postcoloniality Without Race?," 764.

19. Rucker-Chang and Ohueri, "A Moment of Reckoning," 216, 219.

20. Goldberg, The Threat of Race, 4.

21. Ibid. 
M.Y. Marinos, Roma, Race and Socially Engaged Television on the Fringes of Europe

22. Maria Todorova, "The Course and Discourses of Bulgarian Nationalism," in Eastern European Nationalism in the Twentieth Century, ed. Peter Sugar (Washington, DC: American University Press, 1995), 71.

23. Annabel Tremlett, "Demotic or Demonic? Race, Class and Gender in 'Gypsy' Reality TV," The Sociological Review 62, no. 2 (2014): 320.

24. Darrick Hamilton, "Neoliberalism and Race," Democracy: A Journal of Ideas 53, (Summer 2019); Arun Kundnani, "The Racial Constitution of Neoliberalism," Race and Class 63, no.1 (2021): 51-69; Darrick Hamilton, "The Racism of Neoliberalism," Evonomics, February 22, 2020, https://evonomics.com/racism-neoliberalism-darrick-hamilton/

25. David Harvey, The Enigma of Capital and the Crisis of Capitalism (Oxford: Oxford University, 2010), 10.

26. Pierre Bourdieu, "The Essence of Neoliberalism," Le Monde Diplomatique, December, 1998.

27. Ognian Kassabov, Ivaylo Atanasov, Vanya Grigorova, Plosak Danak ili Demokratsia? Za Progresivna Danachna Reforma v Balgaria (Sofia: KOI, 2018), 11.

28. Daniel McLaughlin, "Welcome to Bulgaria, The World's Fastest Shrinking Nation," The Irish Times, October 13, 2018, https://www.irishtimes.com/news/world/europe/welcome-to-bulgaria-the-world-s-fastest-shrinking-nation-1.3658819

29. Julia Stoll, "Media usage in Europe - Statistics \& Facts," Statitsa, September 18, 2020, https://www.statista.com/topics/4039/ media-usage-in-europe/

30. Orlin Spassov, "Geography of the Early Internet in Bulgaria: Territorial and Social Configurations," Digital Icons: Studies in Russian, Eurasian and Central European New Media, no. 15 (2016): 67.

31. "Bulgaria Internet Users," Internet Live Stats, accessed April 21, 2021, https://www.internetlivestats.com/internet-users/ bulgarial

32. Sirma Penkova, "Televiziata Ostava Nai-Predpochitanata Media sred Balgarite," Kapital, May 12, 2021, https://www.capital. bg/biznes/media_i_reklama/2021/05/12/4208660_televiziiata_ostava_nai-predpochitanata_media_sred/

33. Irena Reifová, "Shaming the Working Class in Post-Socialist Reality Television," European Journal of Cultural Studies (2020): 1-18; Adina Schneeweis and Katherine Foss, "'Gypsies, Tramps \& Thieves': Examining Representations of Roma Culture in 70 Years of American Television," Journalism \& Mass Communication Quarterly 94, no. 4 (2017): 1146-1171; Anikó Imre, "Screen Gypsies," Framework: The Journal of Cinema and Media 44, no. 2 (Fall 2003): 15-33; Anikó Imre "Love to Hate: National Celebrity and Racial Intimacy on Reality TV," Television \& New Media 16, no. 2 (2015): 103-130; Tremlett, "Demotic or Demonic?"; Anikó Imre, "Whiteness in Post-Socialist Eastern Europe."

34. NZ, ep. 202, May 25, 2019.

35. Nikolaj Nielsen, "Bulgaria Seen as Most Corrupt in EU," EUObserver, January 27, 2016, https://euobserver.com/ justice/132012

36. Etienne Balibar, "Foreword," in Romani Politics in Contemporary Europe: Poverty, Ethnic Mobilization, and the Neoliberal Order, eds. Nando Sigona and Nidhi Trehan (New York: Palgrave, 2009), ix.

37. Paloma Gay y Blasco, "Picturing "Gypsies": Interdisciplinary Approaches to Roma Representation," Third Text 22, no. 3 (May 2008): 300.

38. Matthew Brunwasser, "Bulgaria's vigilante migrant 'hunter'," BBC, March 30, 2016, http://www.bbc.com/news/ magazine-35919068

39. NZ, ep. 114, March 4, 2017.

40. 'Mangal' is a highly derogatory term in reference to the Roma. The word 'mangal' refers to a Middle Eastern barbeque which turns black from the smoke.

41. NZ, ep. 153, April 21, 2018 \& ep. 187, February 2, 2019.

42. Alexandra Oprea, "Romani Feminism in Reactionary Times," Signs: Journal of Women in Culture and Society 38 , no. 1 (2012): 13.

43. Oprea, "Romani Feminism," 12.

44. NZ, ep. 46, May 16, 2015.

45. NZ, ep. 111, February 11, 2017.

46. NZ, ep. 49, June 6, 2015.

47. NZ, ep. 114, March 4, 2017.

48. NZ, ep. 22, November 8, 2014.

49. Denise Hruby, "How to Slow Down the World's Fastest-Shrinking Country," BBC, September 30, 2019, https://www.bbc.com/ worklife/article/20190913-how-to-slow-down-the-worlds-fastest-shrinking-country

50. NZ, ep. 70, January 23, 2016.

51. NZ, ep. 176, November 10, 2018.

52. NZ, ep. 131, September 23, 2017.

53. NZ, ep. 158, April 28, 2018.

54. NZ, ep. 115, March 11, 2017.

55. Alexandra Oprea, "Re-envisioning Social Justice from the Ground Up: Including the Experiences of Romani Women," Essex Human Rights Review 1, no. 1 (2004): 31.

56. Vanya Grigorova, Bedni Sreshtu Bedni [Poor Against Poor] (Sofia, Bulgaria: KOI, 2016$): 7$. 
M.Y. Marinos, Roma, Race and Socially Engaged Television on the Fringes of Europe

57. Vanya Grigorova, 'Narodat’ Sreshtu Sotsialnite Pomoshti ['The People' Against the Social Benefits] (Sofia, Bulgaria: KOI, 2018): 40.

58. See Grigorova, Bedni Sreshtu Bedni.

59. Mario Tanev, "Bulgaria's Northwestern Region is EU's Poorest - Eurostat," SeeNews, March 30, 2017, https://seenews.com/ news/bulgarias-northwestern-region-is-eus-poorest-eurostat-563516

60. Gail Kligman, "On the Social Construction of 'Otherness': Identifying the 'Roma' in Post-Socialist Communities," Review of Sociology 7, no. 2 (2001): 67.

61. NZ, ep. 179, December 1, 2018.

62. NZ, ep. 46, May 16, 2015.

63. Kligman, "On the Social Construction of 'Otherness'," 66.

64. Sudjuk is a dried sausage bent into a horseshoe shape common across the Balkans.

65. NZ, ep.79, March 26, 2016.

66. NZ, ep.40, March 28, 2015.

67. NZ, ep.48, May 30, 2015.

68. NZ, ep.9, May 25, 2014.

69. NZ, ep.49, June 6, 2015

70. NZ, ep.82, April 16, 2016.

71. Svetlozar Kirilov, "Otraziavaneto na Konflikta vav Voivodinovo v Tri Balgarski Onlain Medii" [The Coverage of the Conflict in Voivodinovo by Three Bulgarian Online Media], Annual of Sofia University Faculty of Journalism and Media 1, (2019): 202.

72. Friedrich Engels, The Condition of the Working Class in England (Oxford: Oxford University Press, 2009/1845).

73. NZ, ep. 90, July 11, 2016.

74. Imre, "Screen Gypsies," 24.

75. NZ, ep. 181, December 15, 2018.

76. NZ, ep. 72, February 6, 2016.

77. NZ, ep. 4, April 10, 2014.

78. Nando Sigona and Nidhi Trehan, "Introduction: Romani Politics in Neoliberal Europe," in Romani Politics in Contemporary Europe: Poverty, Ethnic Mobilization, and the Neoliberal Order, eds. Nando Sigona and Nidhi Trehan (New York: Palgrave, 2009$), 2$.

\section{Bi o graphy}

Martin Marinos is an Assistant Professor in the Department of Film Production and Media Studies at Penn State University. His research and teaching areas of specialization include global and comparative media studies, political economy of media, transnational television history, and socialist and post-socialist mass communication. Currently he works on a book manuscript entitled Free to Hate: Media Liberalization and Right-Wing Populism after 1989, which traces how the commercialization of Central and East European media set the stage for the rise of right-wing populism in the region. 